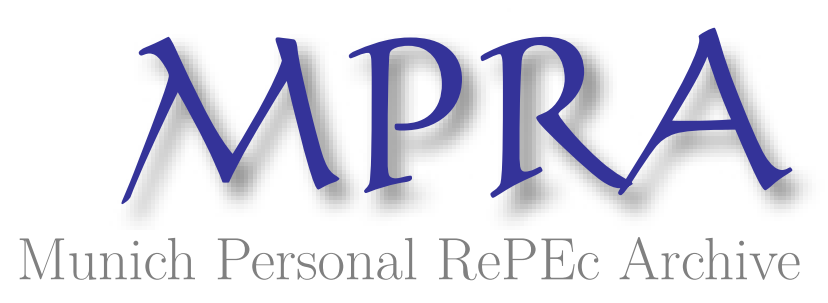

\title{
Determinants of Islamic Banking Growth in Pakistan
}

Shaikh, Salman

1 March 2013

Online at https://mpra.ub.uni-muenchen.de/53798/

MPRA Paper No. 53798, posted 20 Feb 2014 12:33 UTC 


\title{
Determinants of Islamic Banking Growth in Pakistan
}

\author{
Salman Ahmed Shaikh ${ }^{1}$
}

\begin{abstract}
This study analyzes the banks' internal factors to study the determinants of profitability and assets growth. The study also investigates empirically the reasons why Advance to Deposits Ratio (ADR) is low in Islamic banking. Both descriptive and inferential techniques have been used. This is the first inferential study analyzing determinants of profitability in Islamic banks using panel data for the period 2007-12. The results are consistent with theory and other studies conducted in other countries. We find that net markup income is positively associated with expense and assets and negatively with NPLs (Non Performing Loans). Finance to deposits ratio is positively associated with NPL to net income, net markup income and expense to net markup income. Our results suggest that assets growth is positively related with profitability ratios and is also positively influenced by deposits growth.
\end{abstract}

Keywords Islamic Banking, Credit Risk, Bank Profitability, Bank Liquidity, Bank Solvency, ADR, NPL, CAR

\section{JEL Codes G21, G15, E52}

\section{Introduction}

The second phase of Islamic banking in Pakistan got started in 2002. The first phase during the 1980s under the patronage of Zia-ul-Haq was not successful. However, with increased participation of Shari'ah scholars in the policy making, product design, audit and supervision, the second phase has seen impressive and consistent growth. Now, Islamic banking in Pakistan is an established industry with $8 \%$ market share achieved in just over a decade.

Islamic finance is a growing industry almost everywhere. The key regional hubs of Islamic finance include Middle East, South Asia, East Asia and Europe. The industry is growing at a rapid pace and now, it has presence in Africa, Central Asia and North America. Despite the financial crisis of 2007-09 and ongoing credit crisis, Islamic finance has sustained the growth momentum and hence has appeared as a potent, resilient and possibly an alternate financial architecture for postcrisis financial markets.

According to some, this growth owes to some unique features inherent in Islamic financial products. Adel (2010) explained the economic merits of Islamic banking by pointing out that credit expansion through Islamic banking is linked to the growth of the real economy by allowing credit primarily for the purchase of real goods and services. It also requires the creditor to bear the risk of default by prohibiting the sale of debt, thereby ensuring that he evaluates the risk more carefully.

Islamic finance is a broader term. It includes Islamic banking, Islamic insurance known as Takaful and Islamic asset management (Islamic mutual funds etc). Islamic banking is part of Islamic finance, but, both are used interchangeably sometimes. It is because Islamic banking still represents a significant portion of Islamic finance with more institutions, asset base and client

\footnotetext{
${ }^{1}$ Salman Ahmed Shaikh is faculty member at Institute of Business Administration, Karachi. He is pursuing his $\mathrm{PhD}$ in Economics and has written several research papers and articles on Islamic Economics and Finance. He can be contacted at: $\underline{\text { salmanashaikh@iba.edu.pk }}$
} 
base. Furthermore, Islamic banking is practiced more commonly in the world than some of the institutions in Islamic finance which are in development stage.

This study is focused on full-fledged Islamic banks working in Pakistan. In Pakistan, currently there are 5 full-fledged Islamic banks operating and at least 15 conventional banks with Islamic banking branches. Figure 1 depicts the growth trend during the recent years in Islamic banking total assets, deposits and net financing and investments in Pakistan.

\section{Figure 1: Growth Trend in Assets, Deposits \& Net Financing}

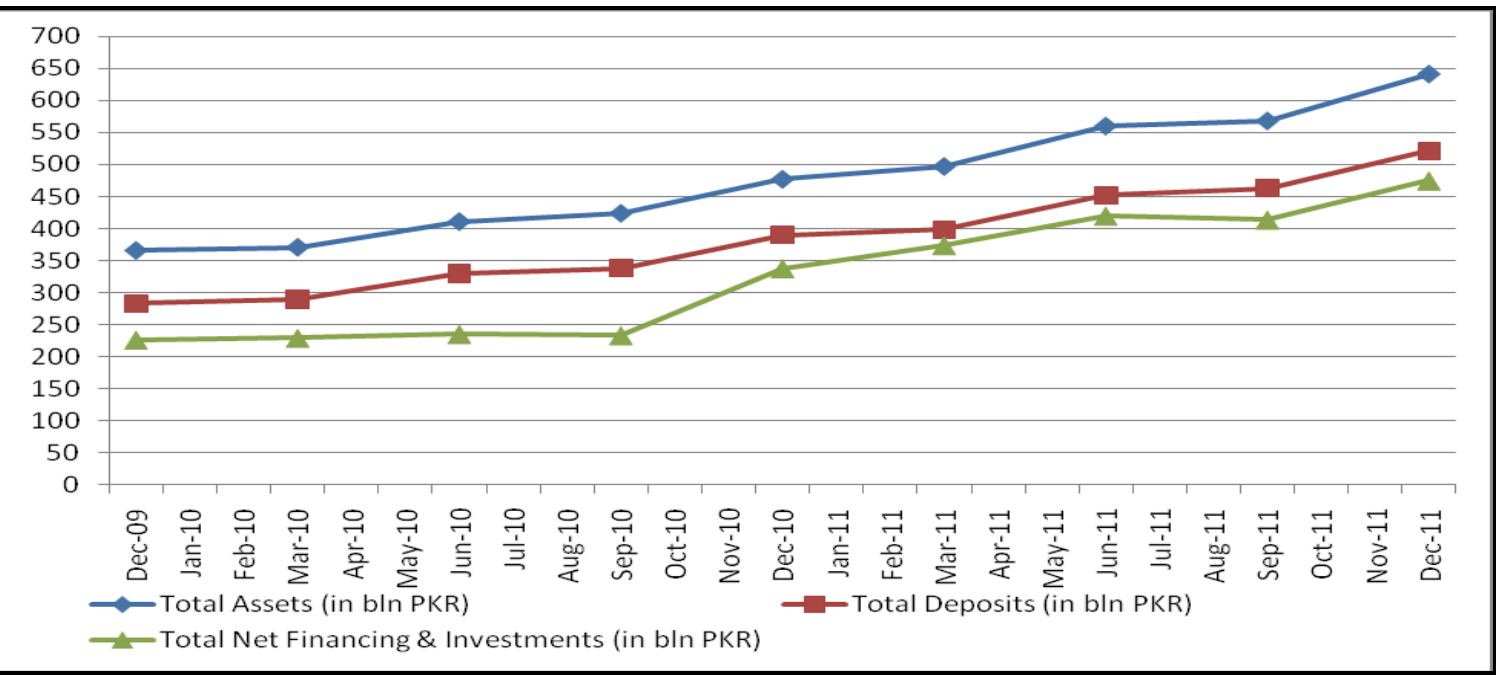

Source: Islamic banking Bulletin, SBP, Various Issues

The share of the Islamic banking industry in the banking system of Pakistan has risen to over 7 percent in 2011 from just 0.5 percent in 2002. Islamic banking now accounts for 7.8 percent of the assets and 8.3 percent of the deposits of the banking sector (Source: SBP Financial Stability Report, pp. 34).

Figure 2: Market Share of Islamic Banking Industry

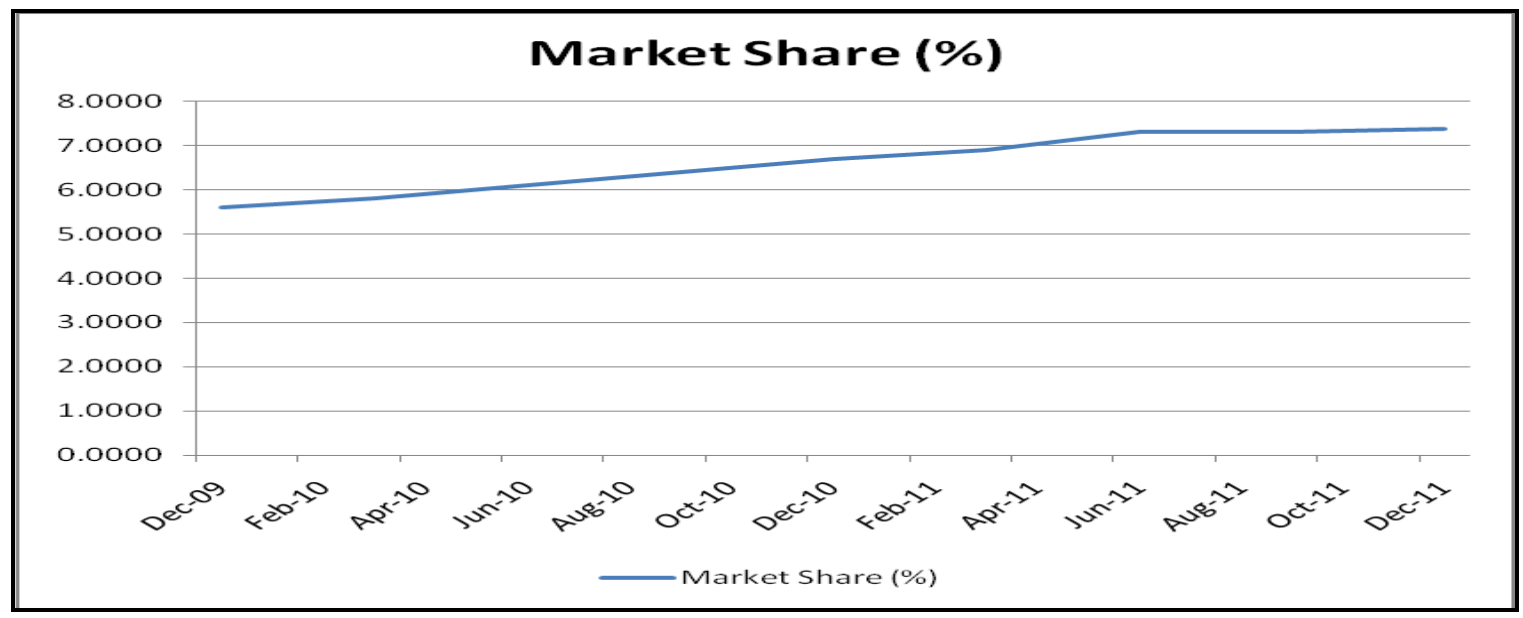

Source: Islamic banking Bulletin, SBP, Various Issues 
In what follows, we give literature review of empirical work done on Islamic banks' profitability and operational efficiency in Section 2. Section 3 discusses various financial ratios that will help us analyze relationships among various banks' internal parameters. Section 4 uses inferential techniques using panel data analysis to study the determinants of profitability, operational efficiency and assets growth. Finally, in section 5, we present a critical note and shortcomings in one decade operations of Islamic banking in Pakistan and we also suggest the way forward for the industry.

\section{Literature Review}

In this section, we cite several studies that have empirically analyzed the determinants of profitability and efficiency in Islamic banks. Hasan (2003) in an empirical study found that high capital and loan-to-asset ratios lead to higher profitability. In his study, he found that the Islamic banks' profitability measures respond positively to the increase in capital and negatively to loan ratios. The results revealed that larger equity to total asset ratio leads to more profit margins.

Analyzing his empirical results, Hasan (2003) explained that adequate capital ratios play a weak empirical role in explaining the performance of Islamic banks. Islamic Banks' loan portfolio is heavily biased towards short-term trade financing. Their loans have low risk and only contribute modestly to the banks' profits.

Using Data Envelopment Analysis, Yodistra (2003) concluded that Islamic banks suffered slight inefficiencies during the global crisis of 1998-9. He indicated that there are diseconomies of scale for small-to medium Islamic banks which suggests that M\&A should be encouraged. Regarding regional differences, he concluded that Islamic banks within the Middle East region are less efficient than their counterparts outside the region. Additionally, market power, which is common in the Middle East, does not significantly have an impact on efficiency. The reason is that Islamic banks from outside the Middle East region are relatively new and very much supported by their regulators. Furthermore, publicly listed Islamic banks are less efficient than their non-listed counterparts.

Using Stochastic Frontier Approach (SFA), Mokhtar inferred that cost and profit efficiencies have improved in Islamic banks and they are relatively better in controlling costs than generating profits. His results also suggest that Islamic banks in Europe are relatively more cost and profit efficient than the other group of banks. Banks in the Middle East region are significantly less efficient than Islamic banks in Africa but more efficient than banks in the Far East and Central Asia.

In another study, Mokhtar (2006) showed that the overall efficiency level in Islamic banks has increased, but it is still lesser than the conventional banks. He inferred that among the Islamic banking institutions, the full-fledged Islamic banks are more efficient than Islamic banking windows.

Haron (2004) in an empirical study discovered that there is positive association between deposits growth and profitability in Islamic banks. He also found that there was no significant variation in earnings between Islamic banks in competitive and monopolistic markets. However, there was strong evidence which indicates that firm's and shareholder's welfare were maximized in the monopolistic market.

Kablan (2011) in an empirical study on bank efficiency found that countries with Islamic banking system do not necessarily display efficiency scores superior to the average. He inferred that the subprime crisis seems to have impacted those banks indirectly. He concluded that Islamic banks do not benefit from scale economy. 
Using cross-country panel data, Basheer (2003) showed that the Islamic banks' profitability measures respond positively to the increase in capital and loan ratios. Their results indicated that the adequate capital ratios and loan portfolios play an empirical role in explaining the performance of Islamic banks. The results also highlighted the importance of consumer and short-term funding, non-markup earning assets, and overheads in promoting banks' profits. The counter intuitive finding about the association between performance and overheads suggests that high profits earned by banks may be appropriated in terms of higher wages and salaries or investment in costly technology used by these banks.

Using data from two Sudanese banks, Bashir (1999) argued that the relationships between size and profitability measures are statistically significant, indicating that Islamic banks become more profitable as they grow in size. The significant negative effect of the risk variable implies that, as the Islamic banks grow in size, the operating risk decreases. This result strongly supports the intermediation theory, which confers a diversification advantage as size increases.

\section{Descriptive Analysis}

In this section, using annual data for the period 2007-12 from the published financial statements of five full-fledged Islamic banks, we present various ratios and their trends over time. Five fullfledged Islamic banks taken for this study include: Meezan Bank Limited (MBL), Bank Islami (BI), Dubai Islamic Bank (DIB), Bank AI-Barakah (BA) and Burj Islamic Bank (BIB).

\subsection{Finance to Deposit Ratio}

It can be seen that finance to deposit ratio for most banks has declined during 2007-12. The possible reasons for that include:

a) Rise in markup rates.

b) High cost of doing business, energy crisis, security crisis etc.

c) Lack of product alternatives to provide distress financing other than for purchase of assets. The demand for such financing is more prominent in a recessionary period.

Figure 3: Finance to Deposit Ratio

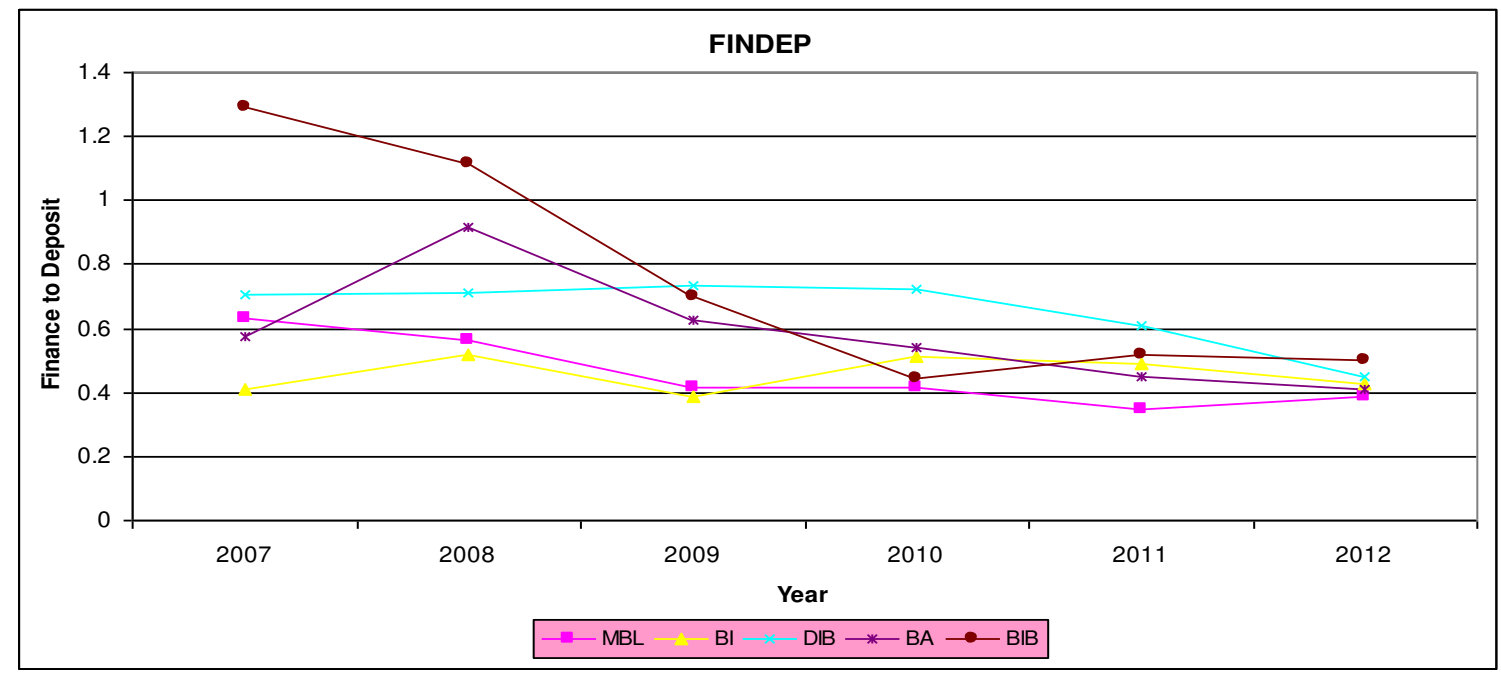




\subsection{Deposit to Total Assets Ratio}

Islamic banks have effectively mobilized deposits and deposit to total assets ratio has steadily increased during the period 2007-12. Though, we defer the empirical analysis of determinants of growth in deposits for the next section, but, here several possible reasons can be highlighted for strong deposit growth and mobilization.

a) Deposit mobilization has much less contractual frictions than creating a Shari'ah compliant financing asset. In providing finance, it is important that finance is provided for genuine purchase of an asset whose ownership, possession and risk has to be borne by bank so as to be able to earn any sale premium or rents for the use of asset.

b) When people become aware of Islamic banking and accept its status as Islamic, most people would start using Islamic banking services first by opening bank accounts than by obtaining finance.

c) It is easier for a customer to switch from conventional bank deposit to Islamic bank deposit than to convert a conventional debt based liability to Islamic financing product.

d) Islamic banks have remained solvent and liquid and hence during and after consumerfinancing bust, people have placed more faith in Islamic banks for parking their surplus funds.

\section{Figure 4: Deposit to Total Assets Ratio}

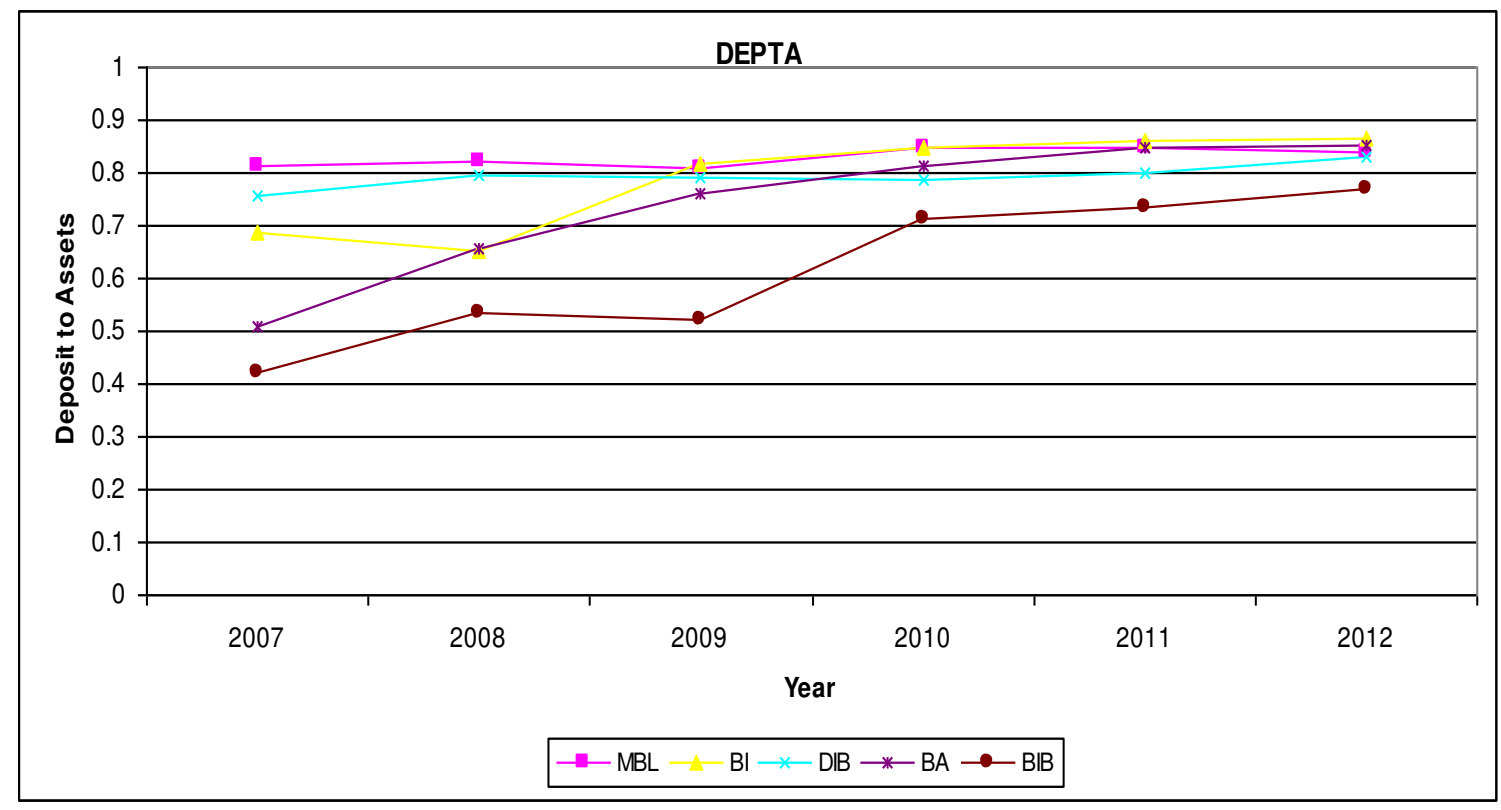

\subsection{NPL to Financing Ratio}

NPL to finance ratio has increased during the consumer-financing bust, but comparatively, Islamic banks have lower NPLs and cleaner balance sheets as compared to conventional banks. After 2010, the ratio is decreasing for all banks in the sample. Possible reasons include:

a) Islamic banks do not provide risky financing, i.e. unsecured loans.

b) Financing is always provided for the purchase of an asset whose ownership belongs to bank.

c) Since Islamic banks can not earn profit on late payments, they only provide financing to sound clients than creating subprime assets. 
Figure 5: NPL to Financing Ratio

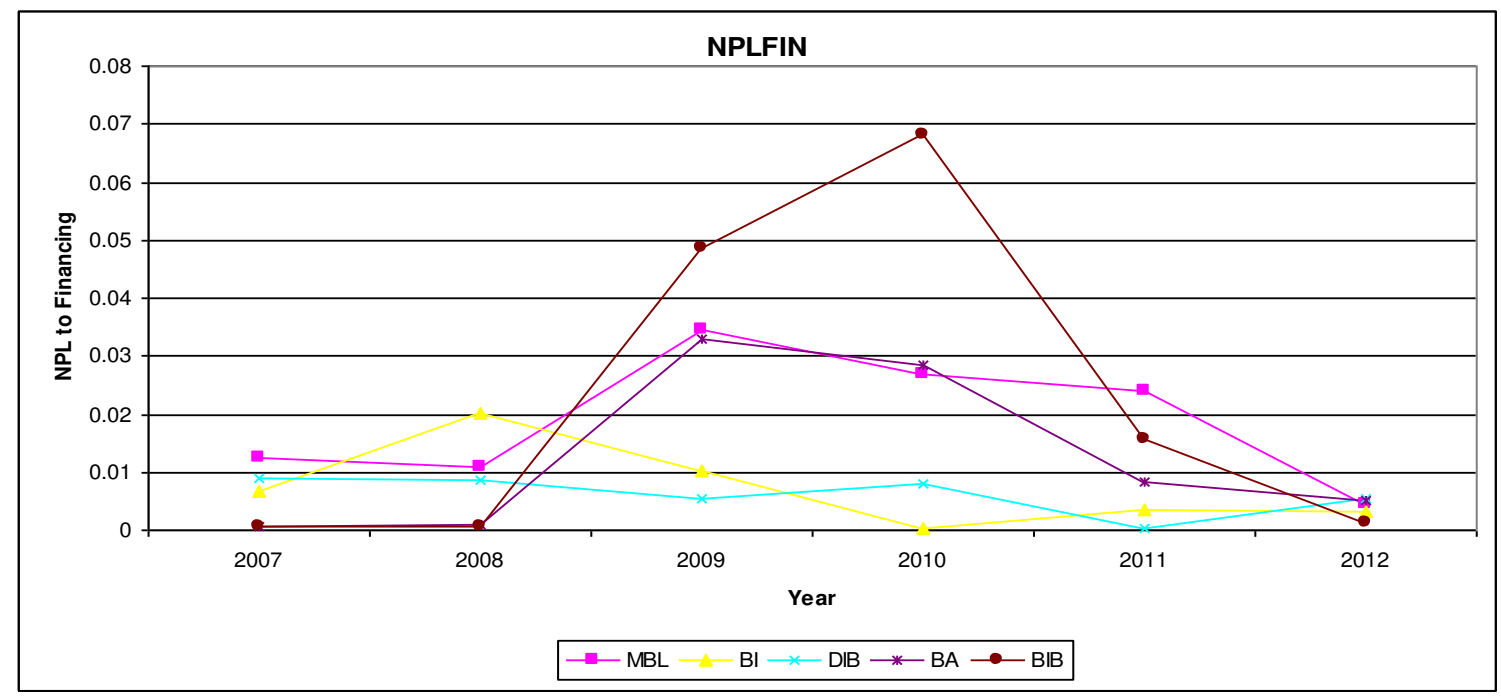

\subsection{Expense to Net Markup Margin Ratio}

This ratio shows that Islamic banks have not achieved scale efficiency yet, but the ratio is declining for some banks and stabilizing for some other banks showing a possible reversal. Hike in this ratio could be attributed to:

a) Expansion.

b) Scale inefficiency.

c) Diseconomies of scale and scope. Each financing contract requires thorough documentation and ascertainment of genuine purchase of an asset.

d) Lack of room to provide every type of loan, like credit cards, running finance, personal finance, travel finance, education finance, health finance etc. 
Figure 6: Expense to Net Markup Margin Ratio

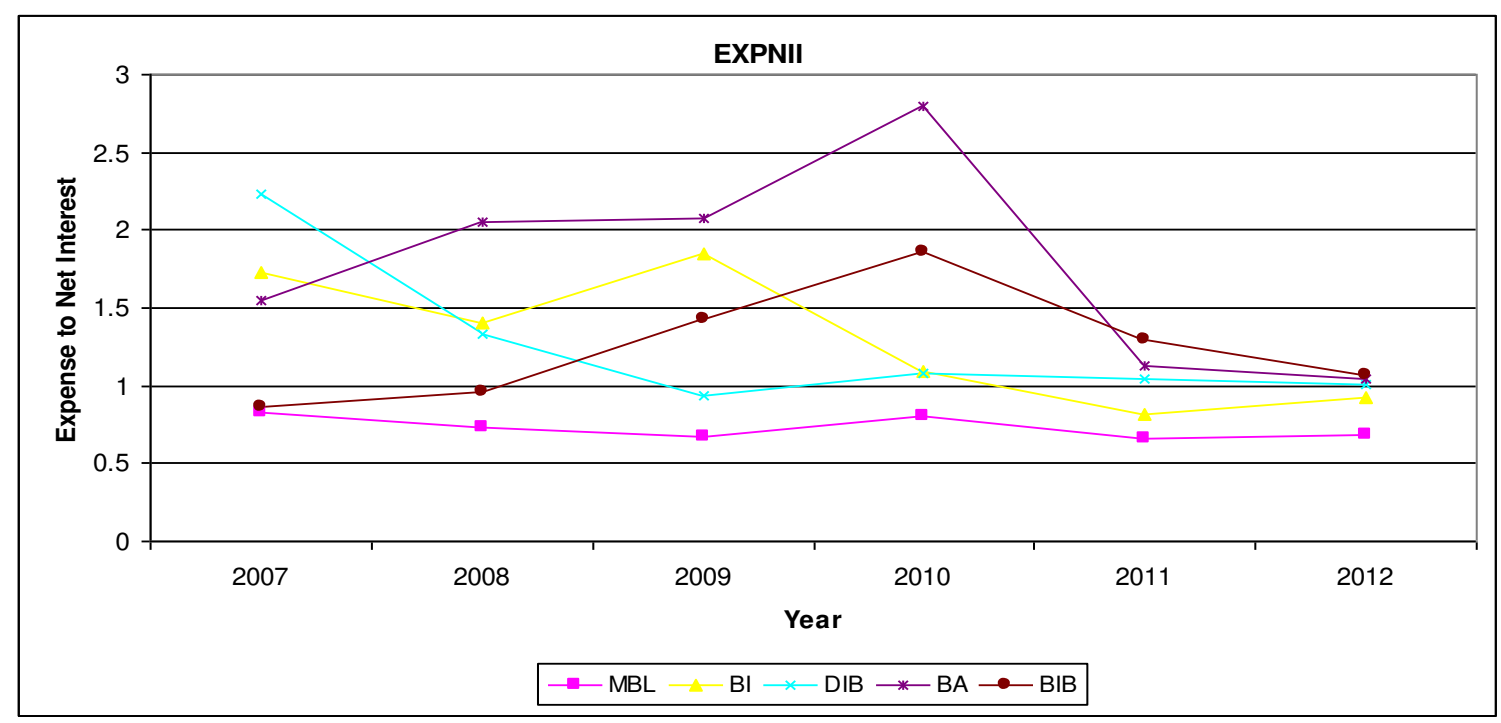

\subsection{Net Markup Margin to Finance Ratio}

This ratio does not present a unique picture or trend. This ratio depends on:

a) Movements in benchmark rate. Rise in benchmark rate will increase this ratio.

b) Any changes in average maturity of financing assets. Increase in average maturity of financing given a normal yield curve will also increase this ratio.

Figure 7: Net Markup Margin to Finance Ratio

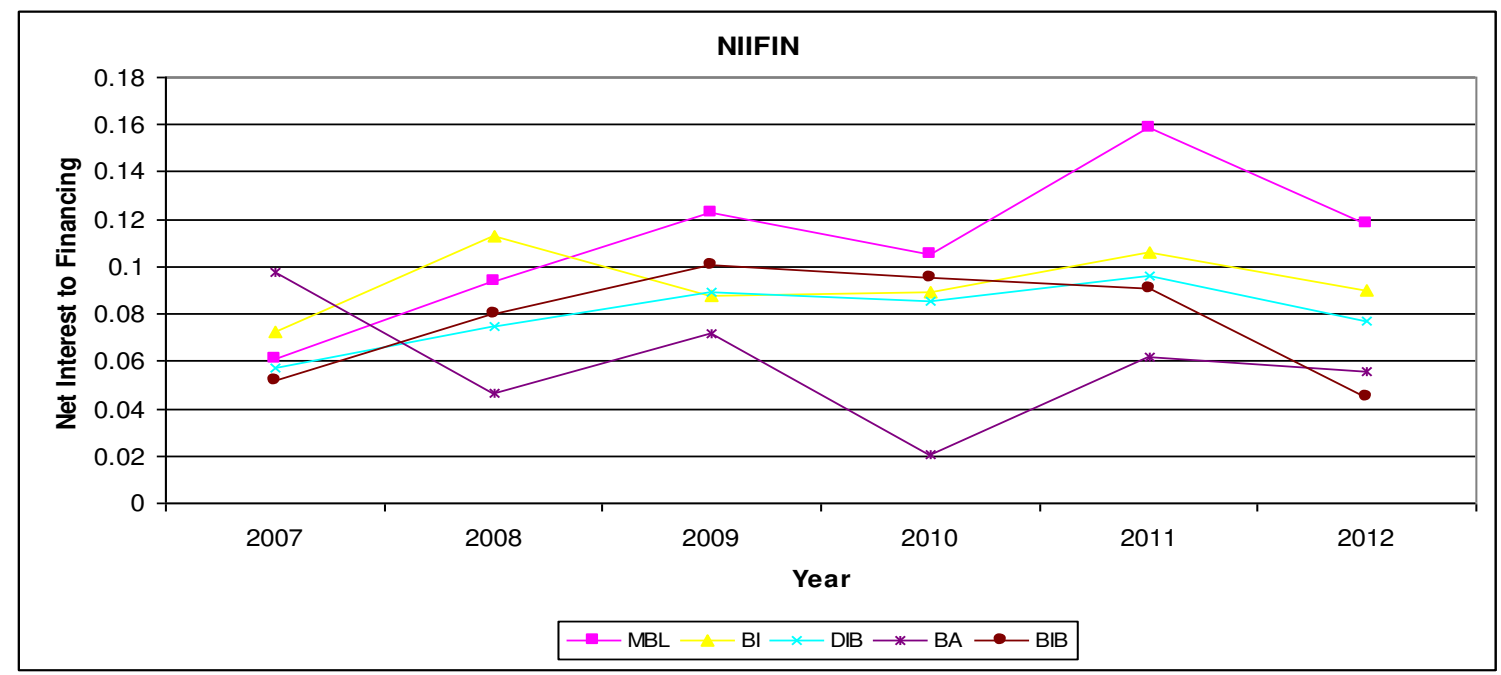

\subsection{Net Income to Financing Ratio}

Most banks had been in losses in their initial years of establishment. This is understandable given the heavy capital expenditure required to set up a bank. Secondly, being a small part of the overall market alongwith increase in number of players in the banking sector of Pakistan during 
90 s and 2000s, Islamic banks at the moment cannot use price skimming to break even quickly. However, all banks taken in the sample currently are now in profits.

Figure 8: Net Income to Financing Ratio

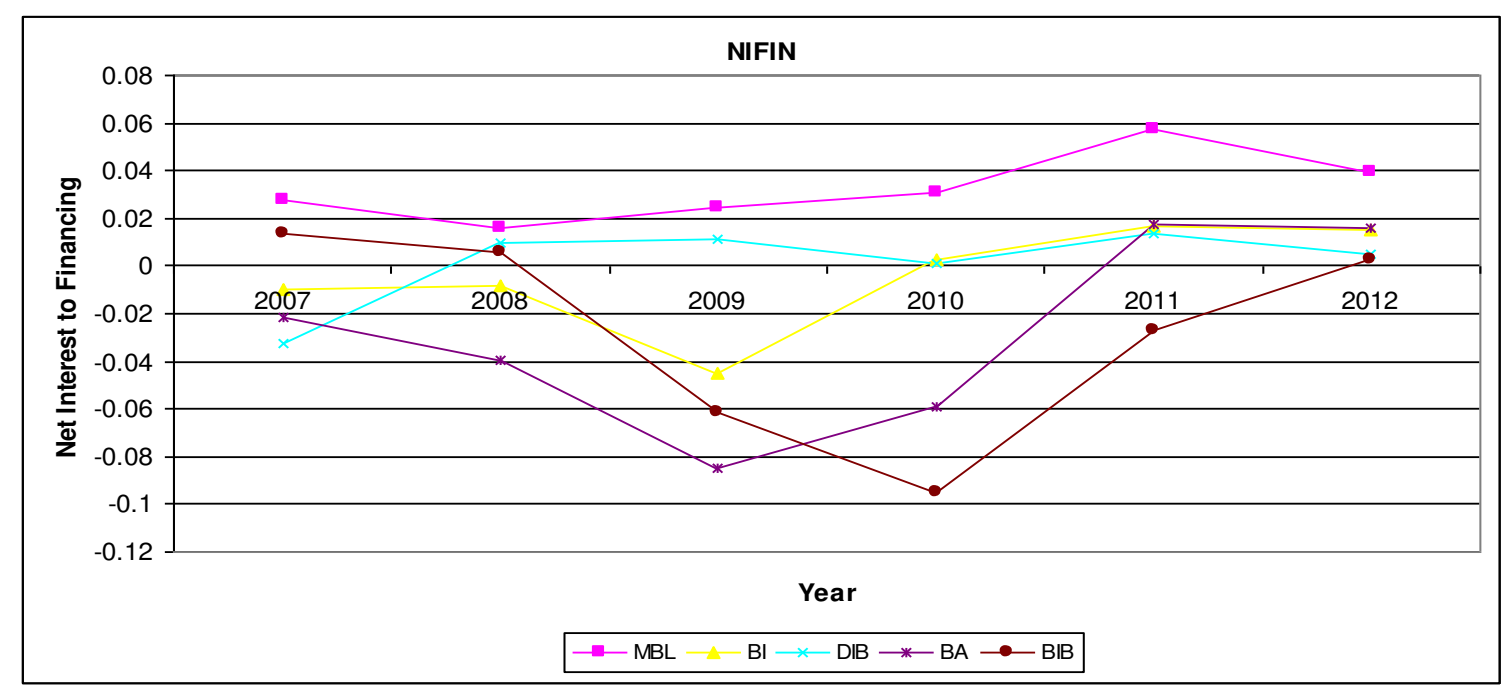

\subsection{Capital to Finance Ratio}

Islamic banks are solvent and have reasonable capital adequacy ratio. With increased penetration and awareness, they are able to park liquidity into financing assets more efficiently than before which is reflected by the decline in this ratio. Market leader during this period has had consistency in this ratio which reflects that there is first mover advantage and dominant firm advantage in the industry.

\section{Figure 9: Capital to Finance Ratio}

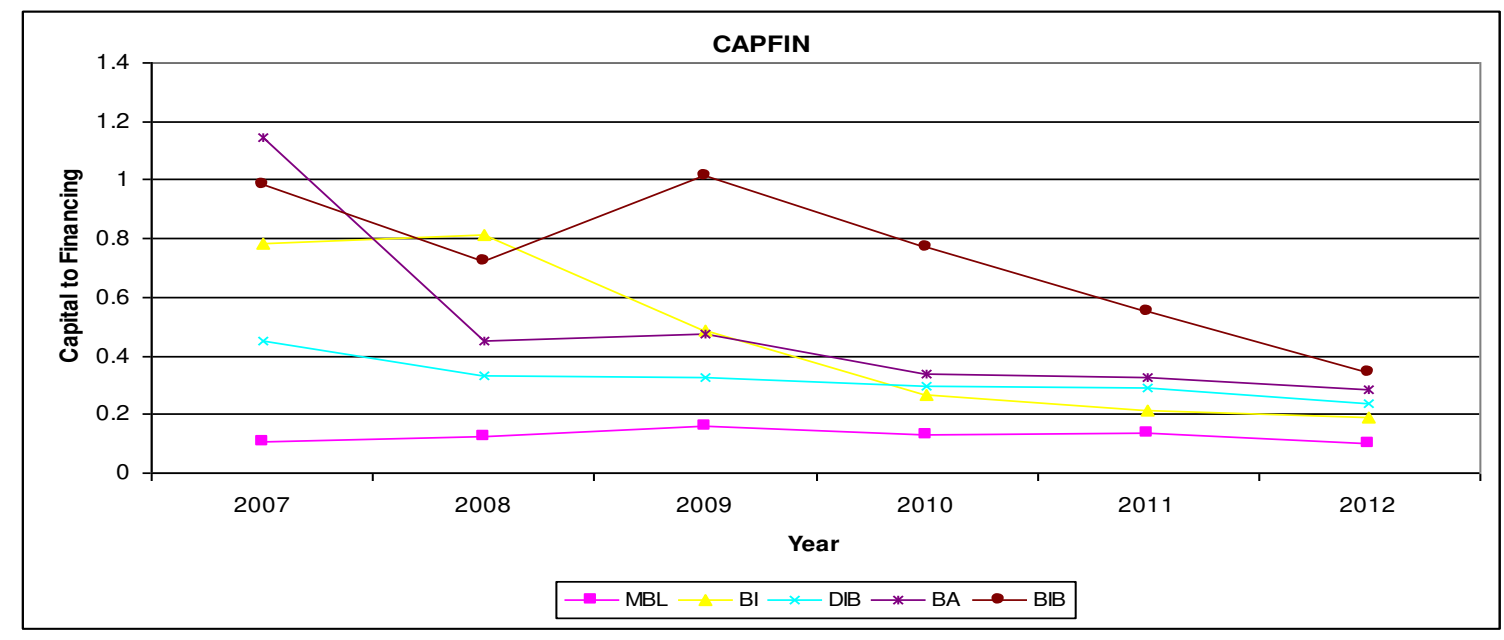

\subsection{NPL to Net Markup Margin Ratio}

NPL to markup margin ratio has increased during the consumer-financing bust, but, comparatively, Islamic banks have lower NPLs as compared to conventional banks due to asset 
backed financing. After 2010, the ratio is decreasing for all banks in the sample. Possible reasons are the same which have been discussed earlier for NPLs to finance ratio.

\section{Figure 10: NPL to Net Markup Margin Ratio}

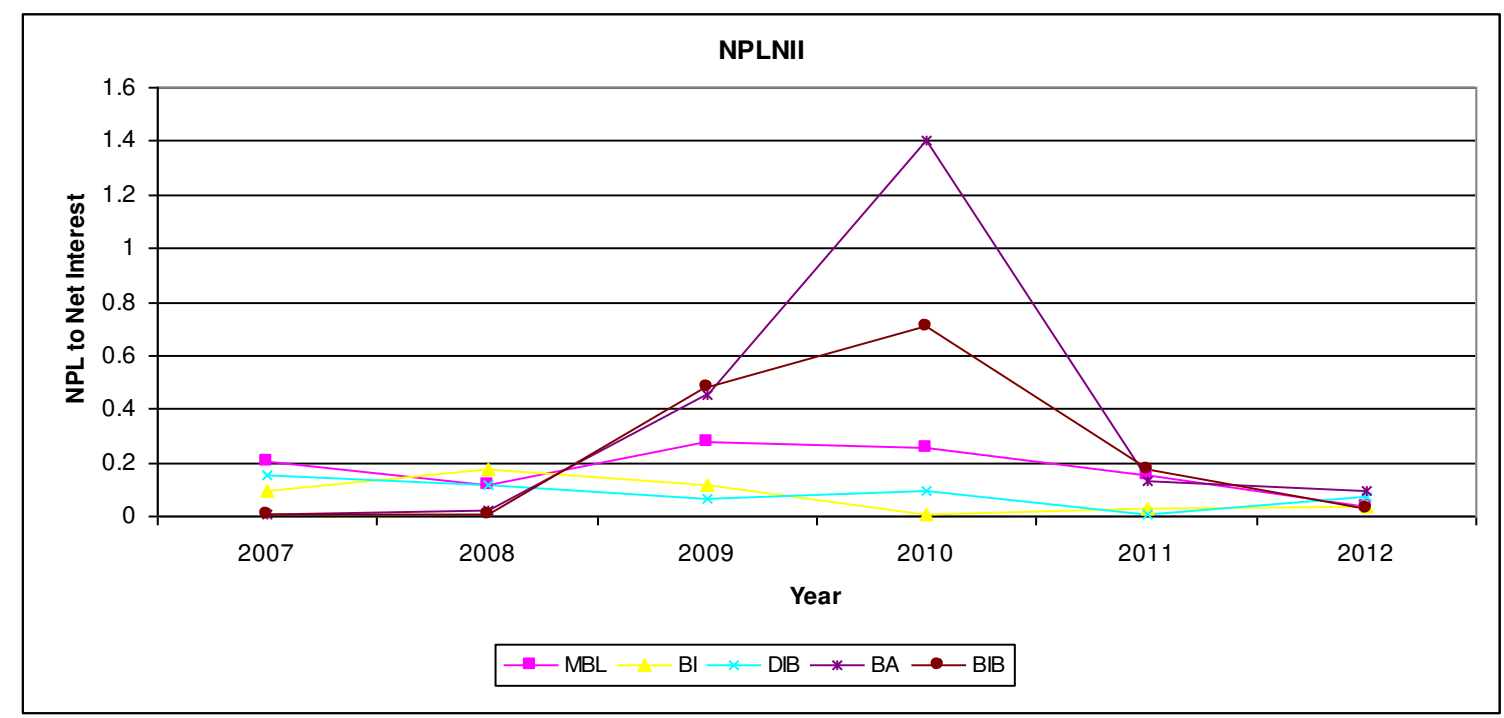

\subsection{Net Income to Total Assets Ratio}

Most banks had been in losses in their initial years of establishment. However, all banks in the sample currently are now in profits. The top two banks have had much stable path for this ratio during the period as compared to new entrants.

Figure 11: Net Income to Total Assets Ratio

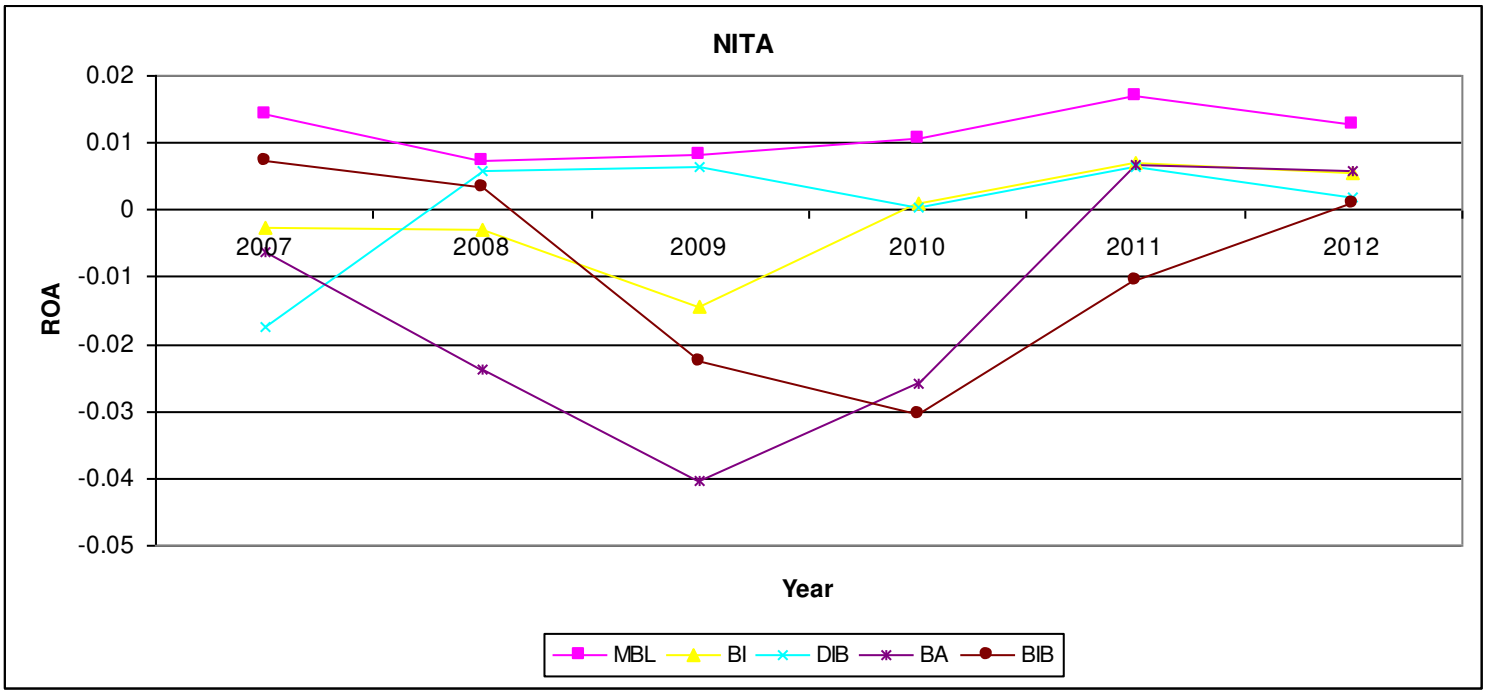




\subsection{Net Markup Margin to Total Assets Ratio}

Fluctuation in benchmark rate, slight rise in NPLs and low ADR has resulted in decline of this ratio in recent years.

Figure 12: Net Markup Margin to Total Assets Ratio

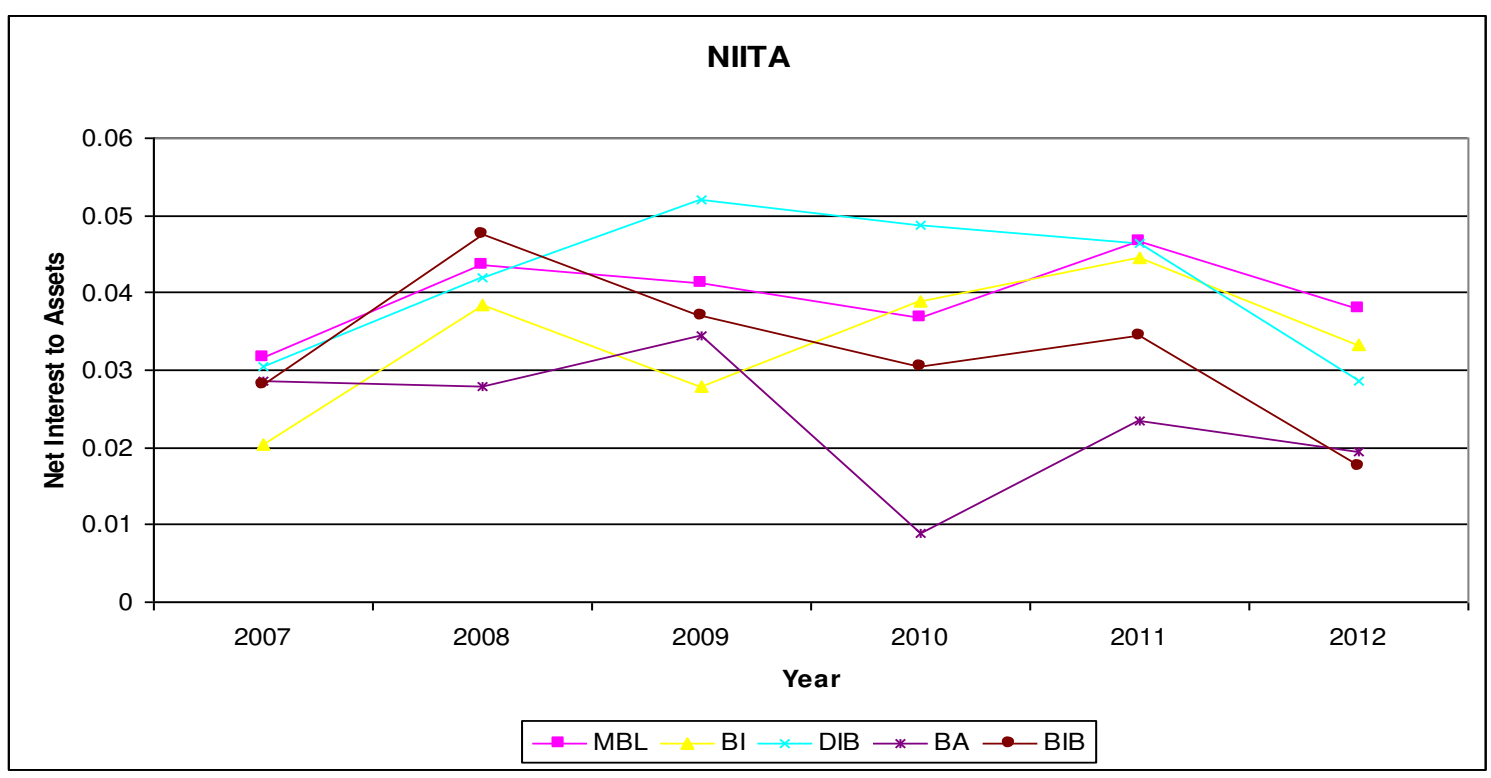

\section{Econometric Analysis}

\subsection{Data \& Methodology}

We have selected five full-fledged Islamic banks in the sample. Annual data for the period 200712 on various internal parameters, i.e. balance sheet and income statement variables is taken. We have also created variables which are important financial ratios used commonly for the analysis of banks.

In total, there are 30 observations $(\mathrm{N}=\mathrm{i} \times \mathrm{t})$, i.e. 6 year data (t) for 5 banks (i). We have a balanced panel. We use panel data regression analysis using fixed effects and random effects. Hausman test of model selection for panel data is employed to decide between fixed effects and random effects model. Using Hausman test, we found that random effects model was more efficient and consistent. Then, we used Breusch-Pagan Lagrange Multiplier (LM) test to decide whether to use random effects or simple pooled regression. As per the results from that test, we finally rested with estimating the panel data regression using random effects GLS regression.

\subsection{Model Specification}

\subsubsection{Model I: Determinants of Profitability}

Specification I

$$
\text { Innii }{ }_{i t}=\beta_{0}+\beta_{1} \text { Inexpense }+\beta_{2} \text { Innpl }+\beta_{3} \text { Inassets }+e_{i t} \ldots \ldots \ldots \text { (i) }
$$

Where 


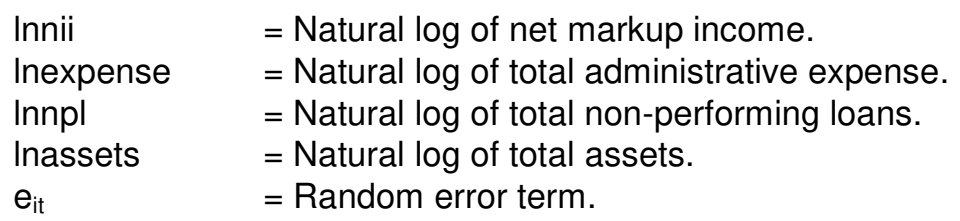

Specification II

$$
\text { Innii }{ }_{i t}=\beta_{0}+\beta_{1} \text { Inexpense }+\beta_{2} \text { Innpl }+\beta_{3} \text { Inadvances }+e_{i t}
$$

Where

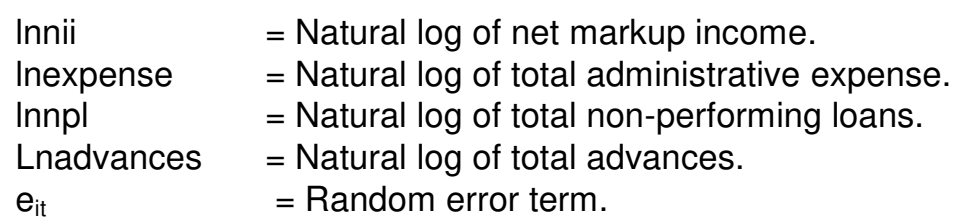

Specification III

$$
\text { Innii } i_{i t}=\beta_{0}+\beta_{1} \text { Inexpense }+\beta_{2} \text { Innpl }+\beta_{3} \text { Incapital }+e_{i t}
$$

Where

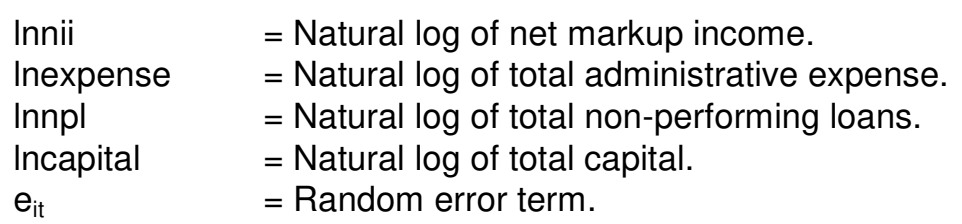

' $i$ ' is cross sectional unit identifier and ' $t$ ' is time identifier.

\subsubsection{Model III: Determinants of Low ADR}

$$
\text { findep }_{\text {it }}=\beta_{0}+\beta_{1} \text { nplfin }+\beta_{2} \text { niita }+\beta_{3} \text { expnii }+e_{i t}
$$

Where

findep = Finance to deposit ratio.

nplfin $=$ NPL to finance ratio.

niita = Net markup income to total assets.

expnii $=$ Expense to net markup income.

$\mathrm{e}_{\mathrm{it}}=$ Random error term.

' $i$ ' is cross sectional unit identifier and ' $t$ ' is time identifier.

\subsubsection{Model IV: Determinants of Assets Growth$$
\text { Inassets }_{i t}=\beta_{0}+\beta_{1} \text { nplni }+\beta_{2} \text { Innii }+\beta_{3} \text { findep }+\beta_{4} \text { depta }+e_{i t}
$$

Where

Inassets $\quad=$ Natural log of total assets.

nplni $\quad=$ NPL to net income ratio. 
$\begin{array}{ll}\text { Innii } & =\text { Natural log of net markup income. } \\ \text { findep } & \text { = Finance to deposit ratio. } \\ \text { depta } & \text { = Deposits to total assets ratio. } \\ e_{i t} & \text { = Random error term. }\end{array}$

' $i$ ' is cross sectional unit identifier and ' $t$ ' is time identifier.

\subsection{Results \& Interpretations}

\subsubsection{Model I: Results \& Analysis}

In the three alternate models for the determinants of profitability, we are able to compute important elasticities by virtue of taking natural log on all variables.

In the first specification, net markup income is positively associated with expense and assets and negatively with NPLs. These results are plausible. Assets growth has coincided with increase in net markup income. Revenue expenditure in expansion has also improved profitability. Increase in NPLs has dented net markup income growth, but only by less than $10 \%$ which is plausible and consistent with observed data.

In second specification, net markup income is positively associated with expense and advances and negatively with NPLs. These results are also plausible. Advances are the major source of markup income and apriori; net markup income should be positively associated with advances growth controlling for NPLs. Revenue expenditure in expansion has also improved profitability. Increase in NPLs has dented net markup income growth, but only by less than $10 \%$ which is plausible and consistent with observed data and earlier model specification.

In third specification, net markup income is positively associated with expense and capital and negatively with NPLs. This is consistent with observed data and earlier model specifications.

Figure 13: Three Alternate Models for Determinants of Profitability

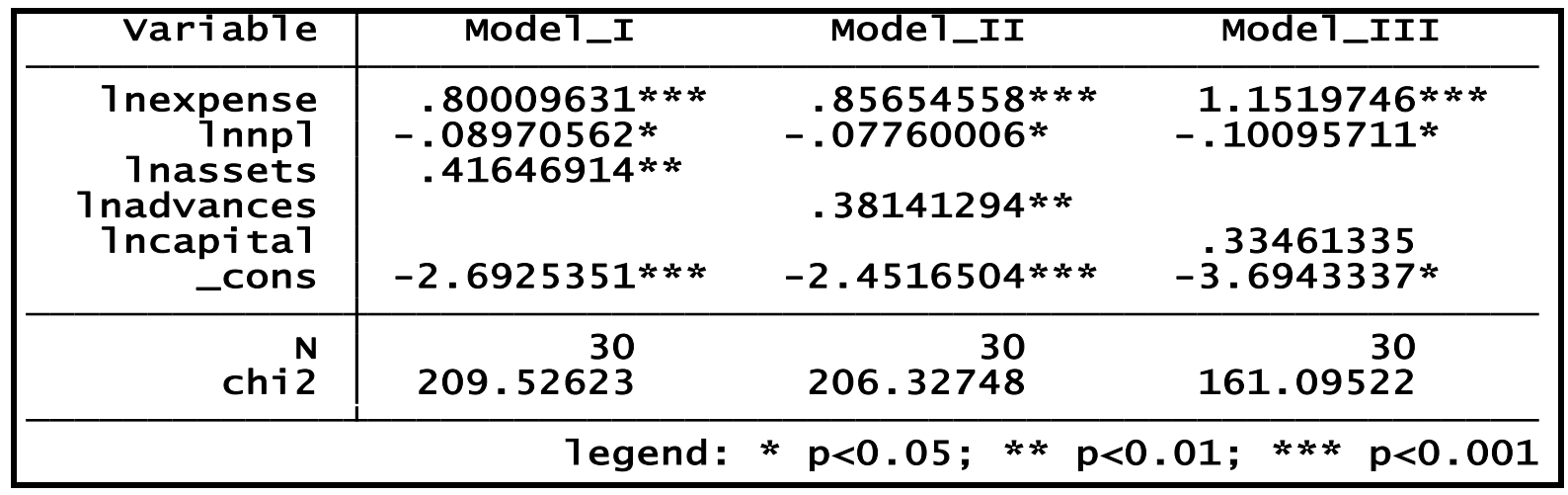

\subsubsection{Model II: Results \& Analysis}

In this model, we try to find determinants of low ADR in Islamic banks. Expense to net markup income is positively associated with finance to deposit ratio. Hence, Islamic banks are only able to improve finance to deposit ratio by increasing inefficiency, i.e. increase in expense to net markup income. This suggests why Islamic banks are slightly expensive in most types of financing that are provided by both conventional and Islamic banks. Finance to deposit ratio is positively associated with NPL to net income and net markup income. Since finance to deposit ratio can increase with increase in NPL to income ratio, Islamic banks have shown risk aversion and have remained satisfied with low finance to deposit ratio and low NPL to income ratio. 
Figure 14: Determinants of Low ADR

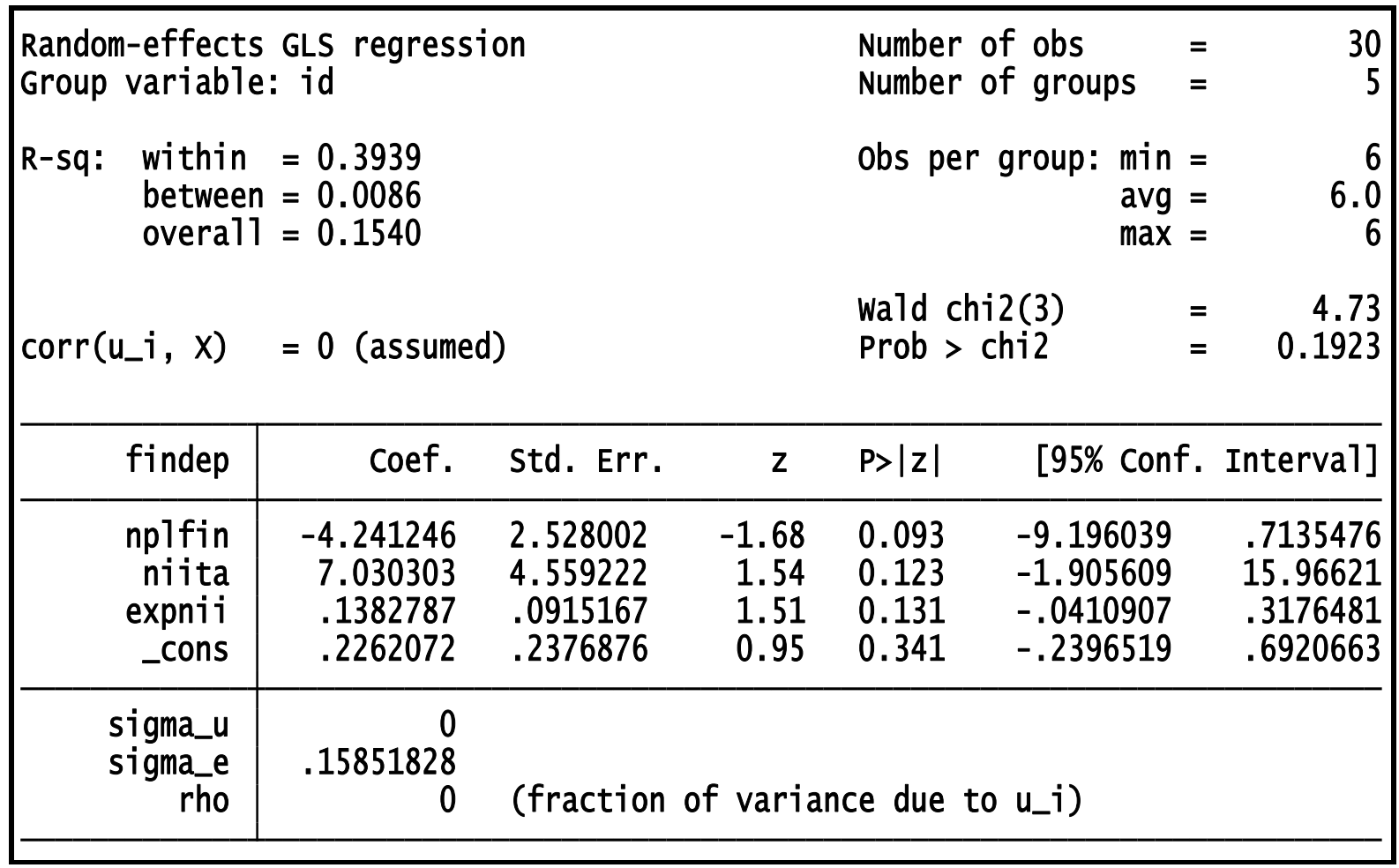

\subsubsection{Model III: Results \& Analysis}

In this model, we try to find the determinants of assets growth. Our results suggest that assets growth is positively related with profitability ratios and is also positively influenced by deposits growth. Negative association between assets growth and finance to deposits ratio is consistent with observed data. In general, increase in finance to deposit ratio is a good signal when financing assets are generated through prudent provision of finance. But, during the period of study, depositors who are leading the assets growth in banks have interpreted decline in finance to deposit ratio as a positive sign amidst high cost of doing business, cost push inflation and high discount rate maintained by the central bank. Hence, they have invested more with Islamic banks considering them more liquid, solvent and prudent in provision of finance. 
Figure 15: Determinants of Assets Growth

\begin{tabular}{|c|c|c|c|c|c|c|c|}
\hline $\begin{array}{l}\text { Random-effects } \\
\text { Group variable }\end{array}$ & $\begin{array}{l}\text { GLS regress } \\
\text { id }\end{array}$ & & & $\begin{array}{l}\text { Number } \\
\text { Number }\end{array}$ & $\begin{array}{l}f \text { obs } \\
f \text { groups }\end{array}$ & $\begin{array}{l}= \\
=\end{array}$ & $\begin{array}{r}30 \\
5\end{array}$ \\
\hline $\begin{aligned} \text { R-sq: } & \text { within } \\
& \text { between } \\
& \text { overall }\end{aligned}$ & $\begin{array}{l}=0.8763 \\
=0.9736 \\
=0.9288\end{array}$ & & & obs $p e$ & $\begin{array}{r}\text { group: } \operatorname{mir} \\
\text { avg } \\
\max \end{array}$ & $\begin{array}{l}= \\
= \\
=\end{array}$ & $\begin{array}{r}6 \\
6.0 \\
6\end{array}$ \\
\hline $\operatorname{corr}\left(u_{-} i, x\right)$ & $=0$ (assume & & & $\begin{array}{l}\text { Wald } \\
\text { Prob }>\end{array}$ & $\begin{array}{l}\text { (4) } \\
i 12\end{array}$ & $\begin{array}{l}= \\
=\end{array}$ & $\begin{array}{l}326.31 \\
0.0000\end{array}$ \\
\hline Inassets & Coef. & Std. Err. & $z$ & $P>|z|$ & {$[95 \%$ cor } & f. & Interval] \\
\hline $\begin{array}{r}\text { nplni } \\
\text { lnnii } \\
\text { findep } \\
\text { depta } \\
\text { _cons }\end{array}$ & $\begin{array}{r}.438624 \\
.704817 \\
-.4207163 \\
1.357937 \\
4.686242\end{array}$ & $\begin{array}{l}.191337 \\
.0816414 \\
.3343663 \\
.7923746 \\
.6491558\end{array}$ & $\begin{array}{r}2.29 \\
8.63 \\
-1.26 \\
1.71 \\
7.22\end{array}$ & $\begin{array}{l}0.022 \\
0.000 \\
0.208 \\
0.087 \\
0.000\end{array}$ & $\begin{array}{r}.063610 \\
.544802 \\
-1.07606 \\
-.195088 \\
3.4139\end{array}$ & & $\begin{array}{l}.8136376 \\
.8648311 \\
.2346295 \\
2.910963 \\
5.958564\end{array}$ \\
\hline $\begin{array}{r}\text { sigma_u } \\
\text { sigma_e } \\
\text { rho }\end{array}$ & $\begin{array}{r}0 \\
.25299806 \\
0\end{array}$ & (fraction & varia & ce due & $u_{-} i$ ) & & \\
\hline
\end{tabular}

\section{Critical Assessment of Islamic Banks \& Way Forward}

Islamic banks after having spent a decade of Islamic banking operations in Pakistan have to reflect on answers to the following points:

- How justified are high Islamic banking spreads (difference between average financing and average deposit rates) which have reached 8.40 percent and are one of the highest in the world and more than two percentage points higher than conventional banks in Pakistan?

- How justified is the argument to seek special privileges from the regulators when Islamic banks use the same benchmark rate, but the difference is that their spreads (margins) are even higher than the conventional banks?

- How do they justify their position and analyze their performance on social and egalitarian grounds when most of their products are priced using the same benchmark of the conventional banking industry, which is KIBOR?

- Equity financing is regarded as the most ideal mode of financing in an Islamic economy by Islamic scholars. Why is it hardly used in financing the clients with a contribution of less than 2 percent in total financing?

- Trust and documentation problems did not hinder 700 companies to get registered on Karachi Stock Exchange while thousands of public limited companies are operating in Pakistan as well. Why Islamic financial institutions could not help support more IPOs either through investment banking operations or alternate institutional structure? 
- Lastly and most importantly, they must reflect on what was the real reason for prohibition of Riba? If it was exploitation, then should an alternate system claiming to be founded on Islamic principles not differ in any substantial way in terms of cost? Unfortunately, if there is any difference, it shows that Islamic financing schemes are costlier than conventional.

Going forward, it is hoped that after having completed one decade of successful operations of Islamic banking and exhibiting exemplary growth in commercial sense, Islamic banks will look towards increasing their outreach to the poor masses and start using more equity based modes of financing which help improve their image and bring some fruits of Islamic economic principles.

\section{Conclusion}

In this study, we analyzed the bank's internal parameters to study determinants of profitability and assets growth. We also investigated empirically the reasons why ADR is low in Islamic banking. Both descriptive and inferential techniques have been used. We found that net markup income is positively associated with expense and assets and negatively with NPLs. Finance to deposit ratio is positively associated with NPL to net income, net markup income and expense to net markup income. Our results suggest that assets growth is positively related with profitability ratios and is also positively influenced by deposits growth.

\section{References}

Adel Ahmed, (2010) "Global Financial Crisis: An Islamic Finance Perspective", International Journal of Islamic and Middle Eastern Finance and Management, Vol. 3 (4), pp.306 320.

Bashir, A. Hameed (2003), "Determinants of Profitability in Islamic Banks: Some Evidence from the Middle East", Islamic Economic Studies, Vol. 11 (1), pp. 33 - 57.

Bashir, A. Hameed (1999), "Risk \& Profitability Measures In Islamic Banks: The Case of Two Sudanese Banks", Islamic Economic Studies, Vol. 6 (2), pp. 1 - 24.

Haron, Sudin (2004), "Determinants of Islamic Bank Profitability", Global Journal of Finance and Economics, Vol 1(1).

Hassan, M. Kabir (2003), "Determinants of Islamic Banking Profitability", ERF Paper, Vol. 10, pp. 3-31.

Kablan, Sandrine \& Yousfi, Ouidad (2011), "Performance of Islamic Banks across the World: An empirical analysis over the period 2001-2008", MPRA Paper 28695, University Library of Munich, Germany.

Mokhtar, H.S.A et al. (2006), "Efficiency of Islamic Banking in Malaysia: A Stochastic Frontier Approach", Journal of Economic Cooperation Among Islamic Countries, Vol 27 (2), pp. 37 -70 .

State Bank of Pakistan [2011]. Islamic banking Bulletin, Issue 3, Karachi.

State Bank of Pakistan [2012]. Financial Stability Review, for $2^{\text {nd }}$ Half 2011 , Karachi.

Tahir, I. Mohammad \& Haron, Sudin (2010) Cost and profit efficiency of Islamic banks: international evidence using the stochastic frontier approach, Banks and Bank Systems, Volume 5 (4), pp. $78-83$. 
Yudistira, Donsyah (2003). Efficiency in Islamic Banking: an Empirical Analysis of 18 Banks. Department of economics, Loughborough University. 